\title{
Let Us Make the Effort: Science into Latin in Antiquity
}

Daryn Lehoux, Queen's University

\begin{abstract}
Scientific writing initially came to ancient Latin speakers as a foreign discipline. Greek-language sources, in the form both of written texts and of living speakers, brought a wide range of philosophical, technical, and scientific material to their Latin neighbors from at least the second century B.C.E. The challenge for the Romans, though, was not just one of translating individual texts - of turning Plato's Timaeus into Latin, for example. Instead, Romans worried and openly reflected on the broader question of what this essay calls discourse translation: Was it possible - at all-even to do philosophy in Latin?
\end{abstract}

Enitar ut Latine loquar.

Let me make the effort to say it in Latin. - Cicero

The scientific name for the great white shark is Carcharodon carcharias. This, amusingly, 1 translates as something like "sawtoothed sawtoothy-shark." While it may lack the majesty of the Tyrannosaurus rex's "king king-lizard," the name certainly does capture a prominent feature of the great white. Another difference between the two names is that when Linnaeus coined C. carcharias, the shark already had a vernacular name. By contrast, the T. rex's name had to be invented in a vacuum, the scientific then becoming the vernacular. Nevertheless, the absence of a vernacular for T. rex was not a complete absence of names, for what Henry Fairfield Osborn did was to call up ready-to-hand Greek and Latin words from which he produced a new designation. The roots were there, but not yet as the name of an animal.

The example points to some of the problems faced by the first translators of scientific and philosophical material from Greek into Latin (Cicero, Lucretius, and others): not all of the words were there yet in the target language. Greeks had been arguing about how the world worked, what it was made of, and why it was the way it was for several centuries before we have any record of Latin speakers becoming interested in joining those conversations. Elaborate technical vocabularies had evolved in Greek, in everything from ethics to astronomy. Latin

Daryn Lehoux is Professor of Classics and Professor of Philosophy at Queen's University. He is the author of Creatures Born of Mud and Slime (Johns Hopkins, 2017), What Did the Romans Know? (Chicago, 2012), and Astronomy, Weather, and Calendars in the Ancient World (Cambridge, 2007), as well as the coeditor (with A. D. Morrison and Alison Sharrock) of Lucretius: Poetry, Philosophy, Science (Oxford, 2013). Department of Classics, Queen's University, Watson Hall 505, Kingston, Ontario K7L 3N6, Canada; lehoux@queensu.ca.

Isis, volume 109, number 2. (C) 2018 by The History of Science Society.

All rights reserved. 0021-1753/2018/0109-0005\$10.00.

308 
had none of this linguistic infill at first, and decisions had to be made about how to remedy the gap. And of course translation is not usually just a process of turning foreign words into domestic ones. The translator also has to think about what he is trying to achieve with a translation, how to manage linguistic nuances, wordplay, and so much more. For educated Romans, though, these questions emerged not just in the context of what I will call textual translation, by which I mean the familiar act of bringing some specific text more or less faithfully from one language into another, but in the context of what we might call discourse translation, the much bigger project of taking a whole discipline that had only ever been spoken and written about in one language, Greek, and trying to engage with it productively in another, Latin. For the Romans, natural philosophy had simply never been done in their language before, and it wasn't obvious to them whether it could be-or indeed whether it even needed to be. After all, cultured Romans were (supposed to be) able to read and speak Greek, so what was the point? Whom was it for? ${ }^{1}$ The issue of discourse translation is doubly interesting in this case, because the early attempts to do natural philosophy in Latin may be the first time in the history of the sciences that the question was actually raised as to whether the act of translation itself was possible or even desirable. Yes, divinatory, medical, astronomical, and calendrical knowledge seems to have moved freely between ancient cultures and languages before the Roman period. ${ }^{2}$ But in the Latin project we see an active and direct engagement with the issue of the possibility of translation. The question was simply this: Could you do philosophy - natural or otherwisein Latin?

As an indication of how early and how deeply pro-Greek sentiment ran in Roman culture, it has always struck me as telling that the first Roman historian, Quintus Fabius Pictor, wrote in Greek, and he did so nearly a century before the Romans actually incorporated Greece into the growing empire in 146 B.C.E. Clearly Greek as a language of education and culture had taken an early hold on its neighbors, and Fabius was making a deliberate decision in this context not to discourse-translate the genre of history. ${ }^{3}$ We do not know his reasons, but the fact speaks for itself: history was written in Greek.

As for philosophical and scientific material, the beginnings of Roman interactions therewith can be traced to at least the mid-second century B.c.E., when the Athenians sent an embassy of philosophers to Rome and when influential public figures like the great Scipio Aemilianus began patronizing and associating with Greek philosophers. And it is something like a century after this that we find our first forays into translating Greek scientific material: the great atomist versification by Lucretius and Cicero's considerable philosophical output. We should note, though, that with Lucretius, as with the vast majority of Cicero's philosophical work outside of his Aratus and Timaeus, ${ }^{4}$ what we see is not textual translation but, instead, an attempt to

\footnotetext{
${ }^{1}$ The question of the tastefulness and desirability of supertitles in opera may be a modern parallel here.

2 The details are often difficult to nail down exactly, but between Akkadian, Egyptian, Hittite, Hebrew, Greek, and other languages something seems to have been passed around from quite an early date. For details see, e.g., O. Neugebauer, The Exact Sciences in Antiquity (Providence, R.I.: Brown Univ. Press, 1957); Markham J. Geller, Ancient Babylonian Medicine: Theory and Practice (Chichester: Blackwell, 2010); William Furley and Victor Gysembergh, Reading the Liver: Papyrological Texts on Ancient Greek Extispicy (Tübingen: Mohr Siebeck, 2015); and Mary R. Bachvarova, "The Transmission of Liver Divination from East to West," Studi Micenei ed Egeo-Anatolici, 2012, 54:143-164.

${ }^{3}$ I thank an anonymous referee for this point.

${ }^{4}$ What has come down to us of Cicero's Timaeus has usually been thought to have been at least an attempt at a stand-alone whole or partial translation of the dialogue that may or may not have been left unfinished at Cicero's death, but David Sedley has argued, in part on the basis of its own introductory material and the cast of characters there introduced, that Cicero was deliberately translating only a section of the Timaeus, intending then to put counterarguments and further discussion in the mouths of his other characters, most prominently Cratippus the Aristotelian. I find this to be a tantalizing possibility. Others,
} 
present the contents of particular doctrines, and to engage with those ideas, in the new language. Today Lucretius is one of our best and most extensive sources for Epicureanism, but he does not claim to be representing the actual words of Epicurus himself. Can we still call this translation? Perhaps not strictly; but it is translation in a very important sense all the same, because the act of bringing Greek philosophy over into Latin, the act of discourse translation, was an important one to its practitioners, and they saw it as a significant task: sometimes to try to raise the level of ethical or political discourse at Rome; sometimes with an eye to Roman or even just authorial self-image; sometimes, at least in part, for the sake of virtuosity. Whatever the individual motivation, Romans themselves saw the work as important and made efforts to justify it explicitly.

In the earliest Roman reflections on the desirability or possibility of translating Greek philosophical or scientific material into Latin, a comparison is made with the activity (and appropriateness) of the earlier Latinizations of Greek epic. ${ }^{5}$ Although later philhellenes such as the second-century C.E. author Aulus Gellius might look down their noses at the Latin when compared to the Greek originals, ${ }^{6}$ people like Cicero thought translations - both discourse and textual-fulfilled an important end, in addition to having literary virtues of their own and contributing to the elevation of Latin culture and morals. Writing at a time when he hoped in vain to save the floundering republic from the tyranny that would soon engulf it, Cicero saw the act of translation as at least partly an attempt to remind Romans of their highest ideals: "quis enim tam inimicus paene nomini Romano est, qui Ennii Medeam aut Antiopam Pacuvii spernat aut reiciat quod se isdem Euripidi fabulis delectari dicat, Latinas litteras oderit?" "Who is so hostile even to being called a Roman, we might say, as to condemn and reject the Medea of Ennius or the Antiope of Pacuvius, saying that he takes pleasure in the same plays by Euripides, but that he hates Latin literature?") A little later he clarifies that his own efforts at translation are intended to make his fellow citizens "more learned," "doctiores." In the Academica he continues in the same vein: "tu vero ... Varro, bene etiam meriturus mihi videris de tuis civibus si eos non modo copia rerum auxeris, ut fecisti, sed etiam verborum" ("and you, ... Varro, would seem to me to be very worthy of praise from your fellow-citizens if you not only increase their store of facts, as you have done, but also of words"). ${ }^{7}$

And here we hit the most common trope in Latin discussions of the problems of translation: the issue of the poverty of Latin vocabulary (and it is important to note that this problem affects both types of translation effort equally, discourse and textual). Again and again, Latin writers are seen worrying about whether they have the very words necessary even to do science and philosophy. Thus Lucretius: "nunc et Anaxagorae scrutemur homoeomerian | quam Grai memorant nec nostra dicere lingua | concedit nobis patrii sermonis egestas, | sed tamen ipsam rem

however, have their doubts. See David N. Sedley, "Cicero and the Timaeus," in Aristotle, Plato, and Pythagoreanism in the First Century B.C.: New Directions for Philosophy, ed. Malcolm Schofield (Cambridge: Cambridge Univ. Press, 2013), pp. 187-205. For dissent from this position see, e.g., C. Lévy, "Cicero and the Timaeus," in Plato's “Timaeus" as Cultural Icon, ed. Gretchen J. Reydams-Schils (Notre Dame, Ind.: Univ. Notre Dame Press, 2003), pp. 95-110; and J. G. F. Powell, Cicero the Philosopher: Twelve Papers (Oxford: Oxford Univ. Press, 1994), Ch. 10

${ }^{5}$ On this see, e.g., Enrica Sciarrino, "The Introduction of Epic in Rome: Cultural Thefts and Social Contests," Arethusa, 2006, 39:449-469.

6 "Set enim si conferas et componas Graeca ipsa, unde illa venerunt, . . . oppido quam iacere atque sordere incipiunt quae Latina sunt" ("If you compare [the Latin versions] and set [them] alongside the Greek from which they came, the Latin ones very much begin to look sad and worthless"): Aulus Gellius, Noctes Atticae 2.23.3 (here and throughout this essay, translations are mine unless otherwise indicated). On Gellius see, e.g., Joseph Howley, Aulus Gellius and Roman Reading Culture: Text, Presence, and Imperial Knowledge in the "Noctes Atticae" (Cambridge: Cambridge Univ. Press, 2018).

${ }^{7}$ Cicero, De finibus 1.4; and Cicero, Academica 1.26. 
facilest exponere verbis" " "now let us look at the homoeomeria of Anaxagoras, as the Greeks call it, which is not possible to say in our language, the lack of our own native terms preventing us, even if the thing itself is easy to explain in words"). Some decades later, the astrological poet Manilius would pick up the same theme: "et, siqua externa referentur nomina lingua, | hoc operis, non vatis erit: non omnia flecti | possunt, et propria melius sub voce notantur" "and if these things are spoken of in the words of a foreign language, this is due to the subject, not the messenger: not all things can be translated; they are better denoted in their own voice"). ${ }^{8}$

Cicero, on the other hand, makes a deliberate effort to work with Latin root words, even if it means coining new forms. Indeed, as is often remarked, the additions Cicero made to Latin vocabulary are significant (imagine doing philosophy without words for "evidence," "essence," "humanity," "morals," or "qualities," among many others). And reworking the language should be perfectly acceptable, as Cicero points out: even the Greeks, once upon a time, did not have words for many important ideas. They, too, needed to coin words to discuss new topics, so why should Latin speakers not be permitted to do the same? ${ }^{9}$ And, indeed, it is important to Cicero's self-image as a Roman that Latin's ability to accommodate these new subjects shows, far from its poverty, one if its strengths: "sentio et saepe disserui Latinam linguam non modo non inopem, ut vulgo purtarent, sed locupletiorem etiam esse quam Graecam" "I believeand have often said - that the Latin language is far from lacking in resources, as is commonly supposed, but is even more rich than the Greek"). This sentiment is of a piece with an idea Cicero elsewhere advocates and that later Latin authors would endorse, which is that the Romans are not just translating Greek material but are improving it: "non quia philosophia Graecis et litteris et doctoribus percipi non posset, sed meum semper iudicium fuit omnia nostros aut invenisse per se sapientius quam Graecos aut accepta ab illis fecisse meliora" "it is not that one couldn't learn philosophy from Greek writings and teachers, but it has always been my opinion that we Romans found out everything for ourselves more wisely than the Greeks did, or else improved the things we got from the Greeks"). ${ }^{10}$

That having been said, the trope that some things were harder to say in Latin than in Greek remained a literary commonplace throughout the Roman period, paralleled in some ways by the refrain made by poets about the difficulty of versifying scientific material. From Lucretius again: "nec me animi fallit Graiorum obscura reperta | difficile illustrare Latinis versibus esse, | multa novis verbis praesertim cum sit agendum | propter egestatem linguae et rerum novitatem" ("it does not escape my notice that the obscure discoveries of the Greeks are difficult to illuminate in Latin verses, especially because it often must be done with new words due to the poverty of our language and the novelty of the subject"). Compare this to Manilius: "certa cum lege canentem | mundus et immenso vatem circumstrepit orbe | vixque soluta suis immittit verba figuris" "the world in its immense sphere echoes round the poet, singing it in fixed meter when its nature is hardly amenable even to prose"). And a little later he points out that he

\footnotetext{
${ }^{8}$ Lucretius, De rerum natura 1.830-834; and Manilius, Astronomica 3.40-43.

${ }^{9}$ Cicero, Acad. 1.25-26. I get the sense that Cicero thinks one should have considerable latitude, in Greek or Latin, to make up words or rework existing ones. By contrast, in Plato's Cratylus (as an anonymous referee reminded me) the character Cratylus argued that words were inherent to their referents in the sense that the word naturally captured the true essence of the thing it indicated and could never truly be swapped for some other word. True names could never be adopted by convention or simple fiat, as both Cicero and Socrates in the Cratylus seem so comfortable with doing. Note that Cratylus's claim is similar to, but importantly distinct from, the claim in some traditions that some specific language captures the true nature of things. As the Cratylus makes clear, the Egyptians may make axes differently than I do, but their axes still conform to the nature of wood and to the nature of chopping.

${ }^{10}$ Cicero, De fin. 1.10; and Cicero, Tusculanae disputationes 1.1. See also e.g., Cicero, De re publica 3.5 f.; and Mary Beagon, The Elder Pliny on the Human Animal: Natural History Book VII (Oxford: Oxford Univ. Press, 2005), p. 50 f.
} 
is the first even to try to treat of astrology in verse at all: "hoc mihi surgit opus non ullis ante sacratum | carminibus" "this work rises up to me, never before consecrated by others in verse"). In both Manilius and Lucretius, the effect of this poetic self-consciousness is to produce in the reader a sense of what Katherina Volk has called "poetic simultaneity," a sense that the poem is coming to be before the reader's very eyes. Something similar is happening, I want to suggest, in the self-conscious reflections throughout Roman scientific literature on the question of translation into Latin. Even when the project is no longer new, reflections on the Latinizing of natural philosophy lend a vividness to an author's project and make a claim for an important novelty. Even as late as the fourth century C.E., we find the astrologer Firmicus Maternus reporting that others before him had despaired of translating astrological doctrine "because of the limitations of the Latin language (propter Latini sermonis angustias)." But he, through his diligence and hard work, has found a way to take advantage of "the manifest freedoms of the language of the Romans (ostensa Romani sermonis licentia)" to bring the "divine science" to all Romans. ${ }^{11}$

And this, perhaps, is the main point. Aulus Gellius might think that Latin translations paled in comparison to Greek, but the translators of Greek science disagreed, seeing the engagement with natural philosophy as not only possible in their own language but very strongly desirable. Fluency in Greek may have been an important part of the educated Roman self-image, but, as Cicero observed, this was sometimes more honored in the breach. ${ }^{12}$ And in any case, at a time of great political upheaval, just as the old republican system of government was disintegrating, the projects undertaken by Cicero and Lucretius to bring the best of Greek philosophy into Latin had everything to do with establishing a new kind of Roman self-image, one that actively cultivated political virtue over financial gain. The fact that both of their ethical theories were rooted in conceptions of nature as lawlike meant that natural philosophy was an important part of those projects. That it could be done in Latin they wanted to prove. That it should they had no doubt.

\footnotetext{
${ }^{11}$ Lucretius, DRN 1.136-139; Manilius, Astron. 1.22-24, 113-114; Katherina Volk, "Cum carmine crescit et annus: Ovid's Fasti and the Poetics of Simultaneity," Transactions of the American Philological Association, 1997, 127:287-313; and Firmicus Maternus, Mathesis 4.pr.5.

${ }^{12}$ Cicero, De fin. 1.10.
} 